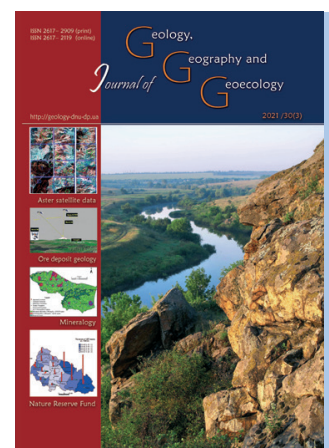

Journal of Geology.

ISSN 2617-2909 (print)

ISSN 2617-2119 (online)

Geography and

Geoecology

Journ. Geol. Geograph.

Geology,

30(3), 480-490.

Journal home page: geology-dnu.dp.ua

doi: $10.15421 / 112144$

Klok S. V., Kornus A. O.

Geol. Geograph. Geoecology, 30(3), 490-490

\title{
Intra-annual and long-periodic components in the changes of precipitation over the Antarctic Peninsula and their possible causes
}

\author{
Serhii V. Klok ${ }^{1}$, Anatolii O. Kornus ${ }^{2}$ \\ ${ }^{1}$ Ukrainian Hydrometeorological Institute, Kyiv, Ukraine, e-mail: sklok_8@ukr.net \\ ${ }^{2}$ Sumy State Pedagogical University named after A.S. Makarenko, Sumȳ,Ukraine, e-mail: a_kornus@ukr.net
}

Received: 14.03 .2021

Received in revised form: 27.03 .2021

Accepted: 29.06.2021

Abstract. In order to identify and study the main mechanisms of the formation of atmospheric precipitation, in the article the monthly and annual amounts of precipitation were analyzed from the observations results at Vernadsky, Bellingshausen and Grytviken stations. For the last station, a small linear trend of precipitation increase was detected, while at Vernadsky and Bellingshausen station it is practically absent. At the next stage of the study, the characteristics of intra-annual component of the precipitation variability for these stations were obtained. In the annual course, the component of precipitation variability is represented by 3 peaks - March, July and October (at Bellingshausen station March and July only), with a well-pronounced 4-year periodicity. However, data from Vernadsky station indicates a decrease of the seasonal component in time, at Grytviken station the seasonal component is stable, while at Bellingshausen station is increasing of the seasonal component in time. The analysis of long-period components of the precipitation variability of was carried out on the remains of the data obtained after the analysis of the intra-annual component. For the long-period component of precipitation variability at Vernadsky station, five statistically significant harmonics were obtained, which are reflected in periods of $6.8,2.4,4.0,5.1$, and 5.3 years. For Grytviken and Bellingshausen stations, 4 statistically significant harmonics were obtained, the periods of which are 4.2, 0.8, 1.7, 8.9 years and 1.5, 2.0, 2.8, 0.2 years, respectively. Today, the main phases of solar activity are well known, which are about 11 years old. The long-period components of precipitation variability obtained in the work for the stations under consideration (to 10.3, 12 and 34.1 years) are identical (close) to the mentioned phase of solar activity. This allowed the authors to draw preliminary conclusions about the influence of solar activity on the conditions for the formation of precipitation in the region under study. However, direct correlation analysis did not confirm this, as in the case of the El Niño influence.

Keywords: atmospheric precipitation, intra-annual distribution, long-period precipitation variability, solar forcing, El Niño.

\section{Сезонні і довгоперіодичні складові у зміні кількості атмосферних опадів в районі Антарктичного півострова та їх можливі причини}

\author{
С. В. Клок ${ }^{1}$, А. О. Корнус ${ }^{2}$ \\ ${ }^{1}$ Украӥнський гідрометеорологічний інститут, Kиїв, Україна, e-mail: sklok_8@ukr.net \\ ${ }^{2}$ Сумський державний педагогічний університет імені A.C. Макаренка, Сум-̄u, Украӥна, e-mail: a_kornus@ukr.net
}

Анотація. 3 метою виявлення і дослідження основних механізмів формування атмосферних опадів, у статті проаналізовано місячні та річні суми опадів за результатами спостережень на станціях Вернадський, Беллінсгаузен та Грютвікен. Для останньої станції виявлено невеликий лінійний тренд до збільшення опадів, тоді як на станціях Вернадський та Беллінсгаузен він практично відсутній. На наступному етапі дослідження були отримані характеристики внутрішньорічної складової мінливості опадів для цих станцій. У річному ході складова мінливості опадів представлена 3 піками, що припадають на березень, липень та жовтень (на станції Беллінсгаузен максимуми опадів лише у березні та липні), з чітко вираженою 4-річною періодичністю. Однак, дані зі станції Вернадський свідчать про зменшення сезонної складової в часі, на станції Грютвікен ця складова стабільна, тоді як на станції Беллінсгаузен сезонна складова мінливості опадів зростає в часі. Аналіз довготермінових компонентів мінливості опадів проведено за залишками даних, отриманих після аналізу внутрішньорічної складової. На станції Вернадський отримано п'ять статистично значущих гармонік, які відображені в періодах $6,8,2,4,4,0$, 5,1 та 5,3 року. Для станції Грютвікен та Беллінсгаузен були отримані по 4 статистично значущих гармоніки, періоди яких становлять 4,2, 0,8, 1,7, 8,9 років і 1,5, 2,0, 2,8, 0,2 роки відповідно. Сьогодні добре відомі основні фази сонячної активності, яким близько 11 років. Довгострокові компоненти мінливості опадів, отримані в роботі для розглянутих станцій (до 10,3 , 12 та 34,1 року), ідентичні (близькі) до згаданої фази сонячної активності. Це дозволило авторам зробити попередні висновки про вплив сонячної активності на умови утворення опадів у досліджуваному регіоні. Однак прямий кореляційний аналіз не підтвердив цього, як у випадку впливу Ель-Ніньо.

Ключові слова: атмосферні опади, внутрішньорічний розподіл, компоненти довгострокової мінливості опадів, сонячна активність, Ель-Ніньо. 


\section{Introduction.}

Changes in rainfall and other forms of precipitation will be one of the most critical factors determining the overall impact of climate change. Precipitation is much more difficult to predict than temperature but there are some statements that scientists can make with confidence about the future. As we know (Trenberth 2011; Lapin et al. 1995; Shukla et al. 2019; Stocker et al. 2013, etc.), changes in precipitation amount during global warming will not be uniform. According to the RCP8.5 scenario (van Vuuren et al. 2011) (The recently published «U. S. National Climate Assessment» shows that we are currently on track for RCP8.5 (Hayhoe et al. 2018)), by the end of this century in high latitudes and the equatorial part of Pacific Ocean, an increase in the average annual rainfall is likely to take place. In many arid regions of mid-latitudes, as well as in subtropics, the average rainfall is likely to decrease, while in many humid regions of mid-latitudes, it is likely to increase by the end of this century (Pachauri et al. 2014). For much of Europe, wetter winters are expected, but with drier summers over central and southern Europe.

The aim of the article is to identify and study the main mechanisms of the formation and changing of the Antarctic Peninsula precipitation as well as searching of their possible causes.

\section{Review of previous research.}

Today there are a big number of publications about precipitation (Averyanov 1990; Sedunov 1991; Bogdanova et al. 2007; Klok 2010, 2013; Thomas 1963; Kirchgäßner 2011; Bromwich 1988; Bryazgin 1982, Cullather et al. 1996; Turner et al. 1995, 1998), but their regional and local features are individual, and they have not been studied enough. Different climate models are in broad agreement about future warming on a global scale, but when it comes to predicting how these changes will affect precipitation amount - there is less agreement at a detailed level. This is especially true of the Polar Regions. For example, current climate models typically represent atmospheric processes only down to scales of about $50-100 \mathrm{~km}$. This limits their ability to incorporate the effects of mountains and coastlines and means that small-scale processes, such as convection, must be represented by average approximations. In addition, the latest regional climate models capture daily rainfall on large scales but are not good at capturing heavier or more localized events (Raveendranathan, 2018).

In addition, it can be assumed that under the conditions of modern climate change, the characteristics of atmospheric precipitation are also undergoing significant changes and require constant updating. All of the above indicates the importance and urgent need to study precipitation, especially in Polar Regions - areas with difficult weather circumstances: long winters, heavy snowfalls, active dynamic conditions.

Snow and other precipitation are the main component the glacial mass gains. According to the estimates by many scientists (Velicogna 2009; Mouginot et al. 2019; Rignot et al. 2019) the ice sheets today are significantly reduced due to thawing. Over the past two decades, the Greenland and Antarctic ice sheets have lost mass (high confidence). Glaciers continued to decline almost all over the world (high confidence). The area of spring snow cover in Northern Hemisphere continued to decline (high confidence). There is a high degree of confidence of the significant regional differences of Antarctic sea ice area trend, and it is very likely that the total sea ice area is increasing (Turner et al. 2014).

The glaciers losing mass, and this contributed to the sea level rise throughout the XX century. It is very likely that the rate of weight loss by the Greenland Ice Sheet increased from 1992 to 2011, which led to more significant rates of total glacial ice loss during 20022011 than from 1992 to 2011. The decadal mass balance of Greenland Ice Sheet switched from a mass gain of $+47 \pm 21 \mathrm{Gt} / \mathrm{y}$ in $1972-1980$ to a loss of $51 \pm 17 \mathrm{Gt} / \mathrm{y}$ in 1980-1990. The mass loss increased from $41 \pm 17$ $\mathrm{Gt} / \mathrm{y}$ in $1990-2000$, to $187 \pm 17 \mathrm{Gt} / \mathrm{y}$ in $2000-2010$, to $286 \pm 20 \mathrm{Gt} / \mathrm{y}$ in $2010-2018$, or six fold since the $1980 \mathrm{~s}$, or $80 \pm 6 \mathrm{Gt} / \mathrm{y}$ per decade, on average. The total Antarctic Ice Sheet mass loss increased from $40 \pm 9$ $\mathrm{Gt} / \mathrm{y}$ in $1979-1990$ to $50 \pm 14 \mathrm{Gt} / \mathrm{y}$ in $1989-2000,166$ $\pm 18 \mathrm{Gt} / \mathrm{y}$ in $1999-2009$, and $252 \pm 26 \mathrm{Gt} / \mathrm{y}$ in 2009 2017. In 2009-2017, the mass loss was dominated by Amundsen/Bellingshausen Sea sectors and Antarctic Peninsula in West Antarctica (Mouginot et al. 2019; Rignot et al. 2019, Pachauri et al. 2014).

Quantifying precipitation in Antarctica faces many unique challenges such as wind and other technical difficulties due to the harsh environment. In view of the logistic difficulty in obtaining reliable precipitation measurements, researchers have resorted to using other means, like satellite observations, reanalysis data sets and climate models (Malcom et al. 2018). But direct measurement of precipitation in Antarctic using ground-based instruments is important to validate the results from climate models, reanalyses and satellite observations. This study compares a variety of natural precipitation measurements in West Antarctica and these data of precipitation measurement can be used as a standard for validating precipitation observations from satellites and the long-term results obtained from climate models and reanalysis data sets.

\section{Material and research methods.}

In this work, we used data from instrumental observations of atmospheric precipitation in the re- 
gion of Ukrainian Antarctic Vernadsky research base $\left(65^{\circ} 14^{\prime} 44^{\prime \prime} \mathrm{S}, 64^{\circ} 15^{\prime} 28^{\prime \prime} \mathrm{W}\right)$ from 1998 to 2018 , Russian Bellingshausen Antarctic station $\left(62^{\circ} 11^{\prime} 55^{\prime \prime} \mathrm{S}\right.$, $\left.58^{\circ} 57^{\prime} 38^{\prime \prime} \mathrm{W}\right)$ from 1998 to 2016 as well as Grytviken meteorological station (British Overseas Territory of South Georgia and South Sandwich Islands) $\left(54^{\circ} 16^{\prime} 53.9^{\prime \prime} \mathrm{S}, 36^{\circ} 30^{\prime} 30.4^{\prime \prime} \mathrm{W}\right)$ for the period of station operation - from 1906 to 1981. All stations are located quite close and represent one geographical area - the northern part of West Antarctica (Fig. 1). The available series of instrumental observation data for precipitation at Antarctica are extremely limited, which is associated, first of all, with the late discovery of the continent, as well as with the limited logistics operations in the region even today. Therefore, the work used the available data on atmospheric precipitation, which are characterized by different periods and duration. However, these series overlap during certain periods of time, which allows the authors to draw conclusions regarding their synchronicity (similarity). As known, the Wolf number (also known as the International sunspot number, relative sunspot number, or Zürich number) is a quantity that measures the number of sunspots and groups of sunspots present on the surface of the Sun. In this work analysed the data from the World sunspot data center of the Royal Observatory of Belgium (Total..., 2020). El Niño-Southern Oscillation (ENSO) is an irregular periodic variation in winds and sea surface temperatures over the tropical eastern Pacific Ocean, affecting the climate of many regions of the world. The El Niño-Southern Oscillation is a single climate phenomenon that periodically fluctuates between three phases: Neutral, El Niño (warming phase of the sea temperature), and La Niña (cooling phase). For our calculations we used the Oceanic Niño Index, prepared by NOAA (Oceanic..., 2020). In the course of the work, well-known methods of mathematical and statistical analysis were used, implemented through the built-in functions of the software Microsoft Excel, Statistica from StatSoft Inc., Surfer from Golden Software LLC.

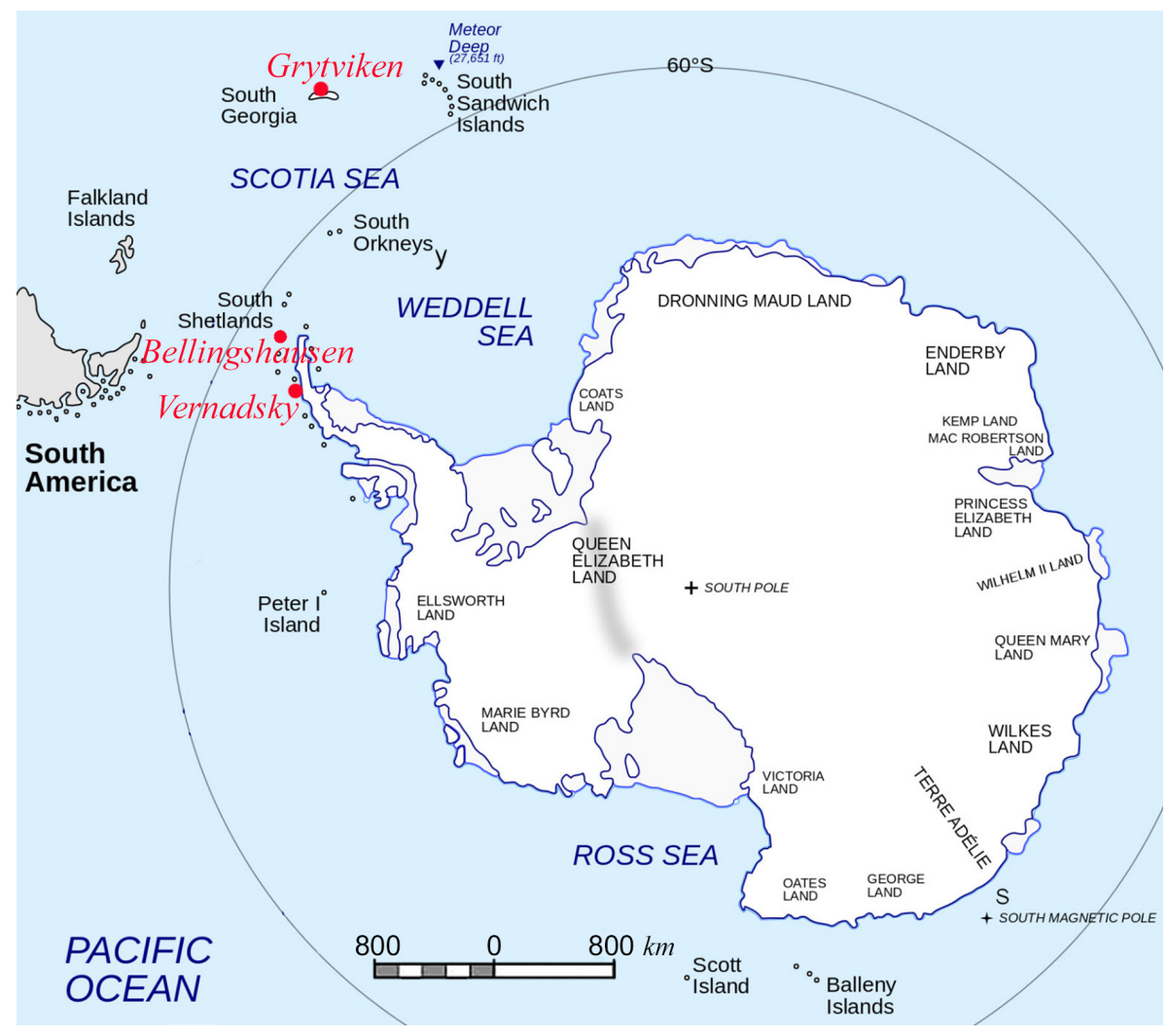

Fig. 1. Location of Vernadsky, Bellingshausen and Grytviken stations where the precipitation data was collected

To analyze the observational data in order to identify the components of the precipitation variability, a harmonic analysis technique was used, i. e. there were obtained trigonometric functions (harmonics) that were multiples of the series length. In this case, the harmonic equation has the following form:

$G_{k}=A_{k^{*}} \cos \left(\omega_{k *} t-\varphi_{k}\right), \quad \omega_{k}=2{ }_{*} \pi / \mathrm{T}_{\mathrm{k}}$, where $k$ is the harmonic number, $\mathrm{A}_{\mathrm{k}}-k^{\text {th }}$ harmonic amplitude, $\omega_{\mathrm{k}}-k^{\text {th }}$ harmonic frequency, $T_{k}-k^{\text {th }}$ harmonic period, $\varphi_{k}-k^{\text {th }}$ harmonic phase, $t$ - time (Brooks 1953).

Full expansion in a Fourier series involves the determination of harmonics, in the amount of $N / 2$, where $N$ is the series length. Harmonic characteristics are determined by finding the Fourier coefficients $a_{k}$ and $b_{k}$ 
are given as: $a_{k}=2 \div N * \sum_{i=1}^{N}\left[x_{i} * \sin \left(\omega_{k} * t_{i}\right)\right]$,

$$
b_{k}=2 \div N * \sum_{i=1}^{N}\left[x_{i} * \cos \left(\omega_{k} * t_{i}\right)\right]
$$

With the aim of the Fourier coefficients calculation by the linear regression method in Microsoft Excel, the sines and cosines of harmonics for a certain date were calculated as used by (Blattner et al.1999):

$\sin _{i}=\sin \left(i \cdot \Omega \cdot\right.$ date $_{2}, \cos _{i}=\cos (i \cdot \Omega \cdot$ date $)$,

where $\Omega=\frac{2 \pi}{T}$; date - date corresponding to the source series value.

The linear regression equations were estimated using the coefficient of determination $(\mathrm{Kd}) \mathrm{R}^{2}$, which is the proportion of the variance in the dependent variable that is predictable from the independent variable(s). The significance of the coefficients was checked by using t-Student's criterion. The F-statistic was used to determine whether the observed relationship between the dependent and independent variables was random.

Results and discussions. The research area is characterized by unstable weather conditions, which are formed under the influence of marine air mass (Averyanov 1990; Sedunov 1991; Bogdanova et al. 2007; Klok 2010, 2013). With unstable weather, often in winter there is precipitation both in the liquid and in the solid phase, which affects the quality of precipitation measurement. In this work, we analyzed the data of monthly precipitation amounts presented in table 1 .

Table 1. Precipitation observation data characteristics

\begin{tabular}{|l|c|c|c|}
\hline \multirow{2}{*}{\multicolumn{1}{|c|}{ Precipitation characteristics }} & \multicolumn{2}{c|}{ Stations } \\
\cline { 2 - 4 } & Vernadsky & Bellingshausen & Grytviken \\
\hline Observation period & $01.1998-12.2018$ & $01.1969-12.2016$ & $91.1906-12.1981$ \\
\hline Number of values & 252 & 576 & 123.1 \\
\hline Average value, mm & 48.6 & 58.1 & 113.4 \\
\hline Median, mm & 43.0 & 54.3 & 98.3 \\
\hline Mode, mm & Multiple & 47.4 & 7 \\
\hline Mode frequency & - & 5 & 465.2 \\
\hline Maximum, mm & 162.1 & 173.0 & 31.05 .1970 \\
\hline Maximum date & 28.02 .2005 & 31.07 .1995 & 10.8 \\
\hline Minimum, mm & 1.9 & 11.7 & 30.09 .1960 \\
\hline Minimum date & 31.12 .2013 & 30.11 .1978 & 65.6 \\
\hline Standard deviation, $\mathrm{mm}$ & 27.7 & 24.3 & 2626.7 \\
\hline Annual maximum, $\mathrm{mm}$ & 733.2 & 991.6 & 888.0 \\
\hline Annual minimum, mm & 379.9 & 471.8 & 1477.3 \\
\hline Average annual value, $\mathrm{mm}$ & 582.7 & 696.9 & \\
\hline
\end{tabular}

The observational data obtained at the stations under study are shown in Fig. 1. Analyzing Table 1 and Fig. 2, it can be concluded that, firstly, the amount of precipitation at Vernadsky and Bellingshausen stations is approximately equal and, secondly, the distribution curves of precipitation at all three stations are very similar. And finally, the analysis of linear trends of the precipitation amount made it possible to establish that only for Grytviken station is a statistically significant positive trend of precipitation, while it is practically absent at Vernadsky and Bellingshausen stations, which is confirmed by the data from Table 2. Perhaps the reason for this is the shorter duration of the time series, limited here to 48 years (Bellingshausen) or even 21 years only (Vernadsky).

Table 2. Characteristics of the linear trends ( $\mathrm{cm} / 10$ years) for precipitation data observation

\begin{tabular}{|l|c|c|c|c|}
\hline \multicolumn{1}{|c|}{ Station } & Observation period duration, year & Value & $\mathrm{K}_{\mathrm{d}}$ & $\mathrm{F}$ \\
\hline Vernadsky & 21 & -0.010 & 0.11 & 0.28 \\
\hline Bellingshausen & 48 & -0.014 & 0.06 & 0.32 \\
\hline Grytviken & 75 & 0.015 & 2.38 & 22.20 \\
\hline
\end{tabular}

Intra-annual variability. At the first stage, the characteristics of intra-annual component of the precipitation amount variability for above indicated stations were obtained. It should be noted that the obtained determination coefficient (in case on Vernadsky station, $\mathrm{Kd}=19.0 \%$ ) indicated what part of the variability this model describes. At the same time,
F-statistics show how trusted the results can be. In our case, $\mathrm{F}=5.6$, which is more than a given threshold value of 2 - for a significance level of 0.95 (Brooks, 1953). For Grytviken station these values are even higher $(\mathrm{Kd}=19.0 \%, \mathrm{~F}=5.6)$ and for Bellingshausen stations $\mathrm{Kd}=10.1 \%, \mathrm{~F}=6.4$. 
In the precipitation annual course, the intra-annual is also represented by three peaks - March, May and component of the precipitation amount variability at August, that is similar to Vernadsky station. At the same Vernadsky station is represented by 3 peaks - March, time, at Bellingshausen station, only 2 maximums are July and October, which is clearly seen from Fig. 3. recorded (March and August), and the annual course of The annual course of precipitation at Grytviken station, precipitation for this station is the most smooth.

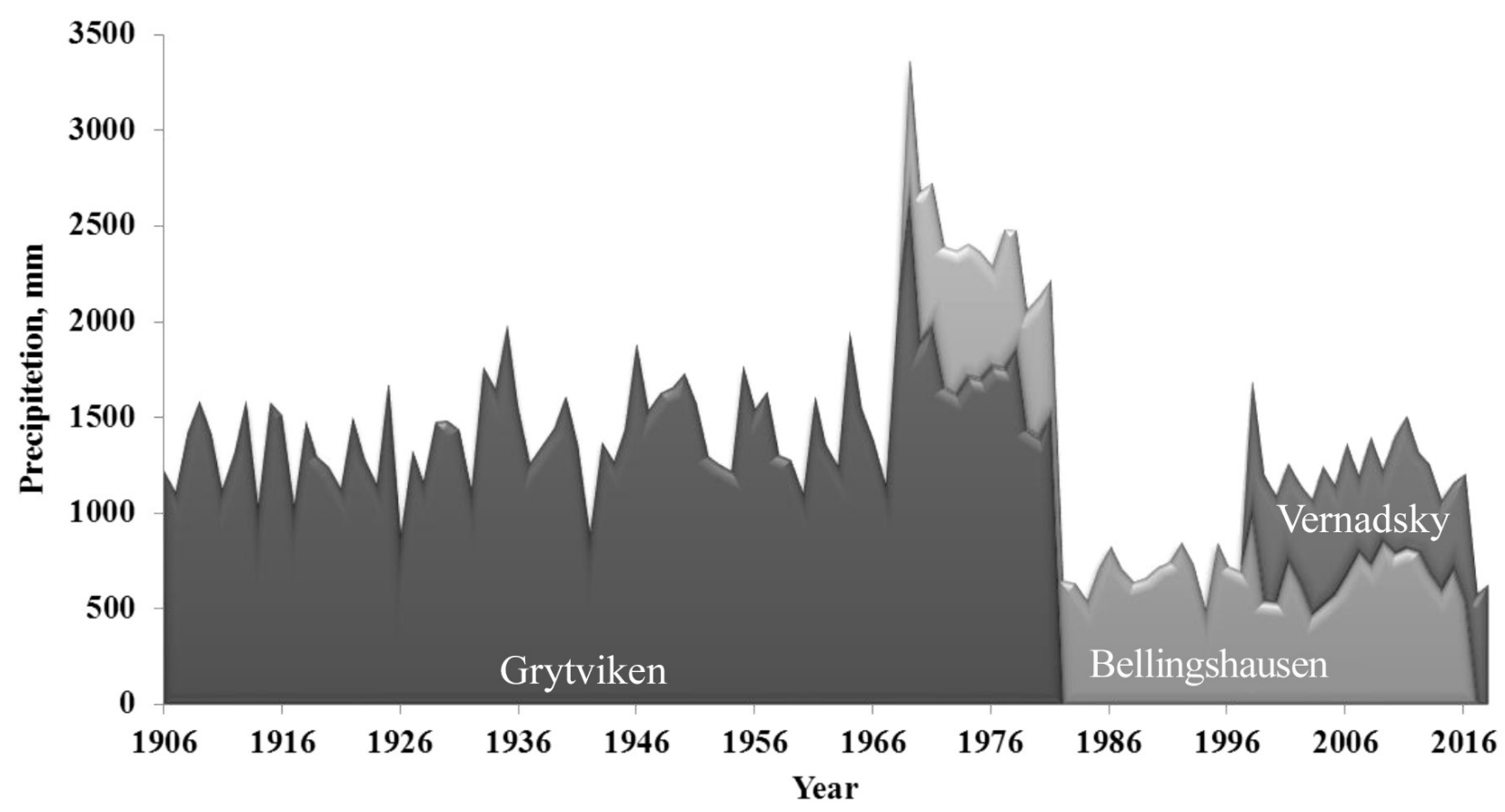

Fig. 2. Temporary distribution of annual precipitation at Vernadsky station during 1998-2018, Bellingshausen station during 19692016 and Grytviken station during 1906-1981.

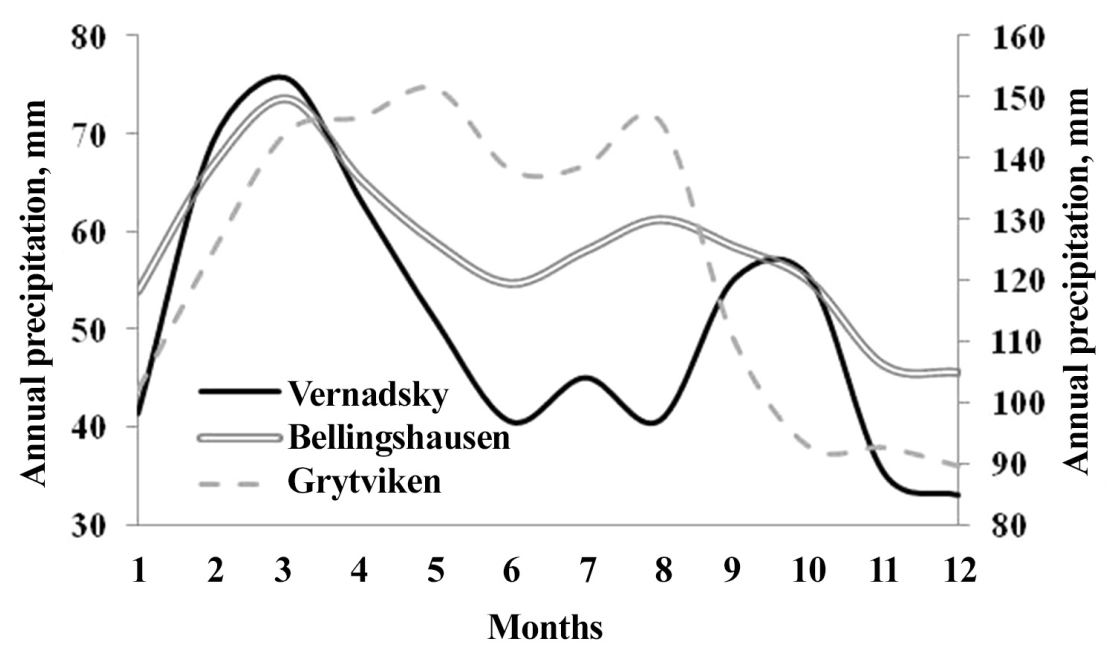

Fig. 3. The calculated curves of the seasonal variation of precipitation at the stations Vernadsky and Bellingshausen (left axis), and Grytviken (right axis).

In addition, the data analysis indicates a decrease of the intra-annual component over time for Vernadsky station. Also, its 4-year periodicity is well displayed; about the nature and possible reasons of it we will make an assumption in this work a little later. At the same time, data for other stations give different results
(Fig. 4). For Grytviken station, there is practically no linear trend, while Bellingshausen station is characterized by an increase of the intra-annual component of precipitation variability over time. However, both stations have a 4-year periodicity, as at Vernadsky station. 


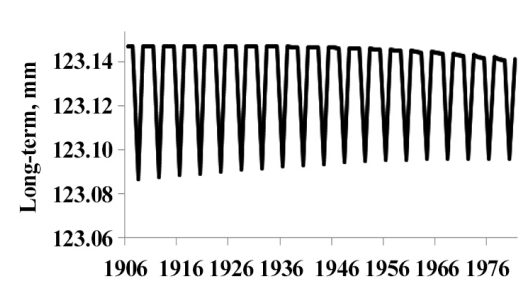

a)

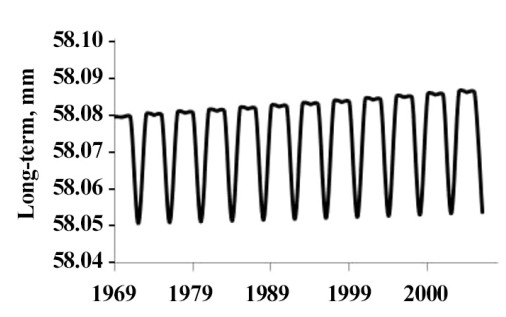

b)

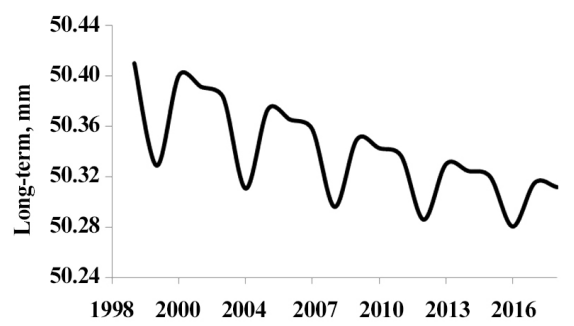

c)

Fig. 4. Long-term dynamics of the precipitation intra-annual component according to the data from Grytviken (a), Bellingshausen (b) and Vernadsky (c) stations.

The analysis of the precipitation variability intra-annual component at the stations under researched can be summarized in the following table 3 .

Table 3. Characteristics of the precipitation variability intra-annual component

\begin{tabular}{|l|c|c|c|c|c|c|}
\hline \multirow{2}{*}{ Station } & \multirow{2}{*}{ Period duration } & \multirow{2}{*}{$\mathrm{K}_{\mathrm{d}}$} & \multirow{2}{*}{$\mathrm{F}$} & \multicolumn{3}{c|}{ Linear trend, $\mathrm{mm} /$ year } \\
\cline { 5 - 8 } & & & & Value & $\mathrm{K}_{\mathrm{d}}$ & $\mathrm{F}$ \\
\hline Vernadsky & 366.1 & 19.0 & 5.6 & -0.010 & 57.70 & 25.96 \\
\hline Bellingshausen & 365.1 & 10.1 & 6.4 & -0.025 & 0.02 & 0.11 \\
\hline Grytviken & 365.4 & 12.5 & 12.9 & -0.013 & 0.11 & 0.08 \\
\hline
\end{tabular}

The obtained amplitudes and phases of statistically significant harmonics of the seasonal variation of precipitation for the studied stations are shown in Fig. 5.
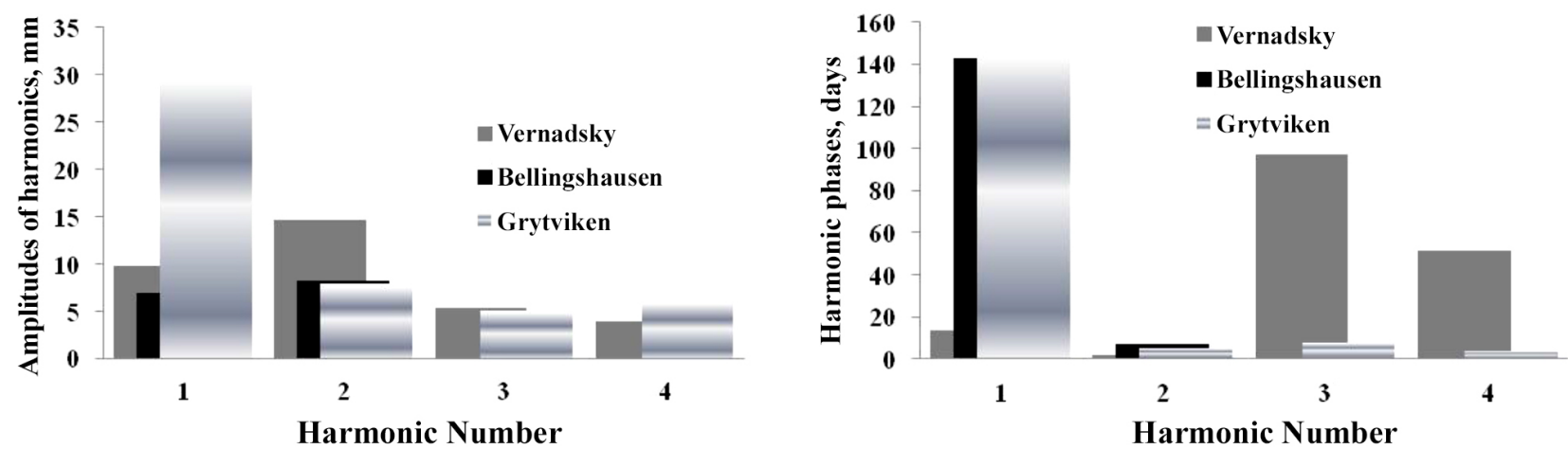

Fig. 5. Amplitudes and phases of harmonic of the intra-annual precipitation variability according to the data from Vernadsky (1998-2018), Grytviken (1906-1981) and Bellingshausen (1969-2016) stations.

The intra-annual component (annual course) of precipitation variability is described in works of other scientists, because it is not necessary to have long series of observations. But the results obtained by the authors are unique for the studied region, especially in terms of long-term changes. In the future, with their help it is possible to develop a scheme for long-term forecasting of weather conditions in the region.

\section{Long-period variability.}

The analysis of the long-period components of the precipitation variability was carried out on the residuals of the data obtained after the analysis of the intraannual component. This made it possible to obtain not only the corresponding harmonics of the distribution, but also to distinguish the boundaries of periods (half periods). The characteristics of the precipitation variability over long periods according to the data from stations under study are shown on Fig. 6. 

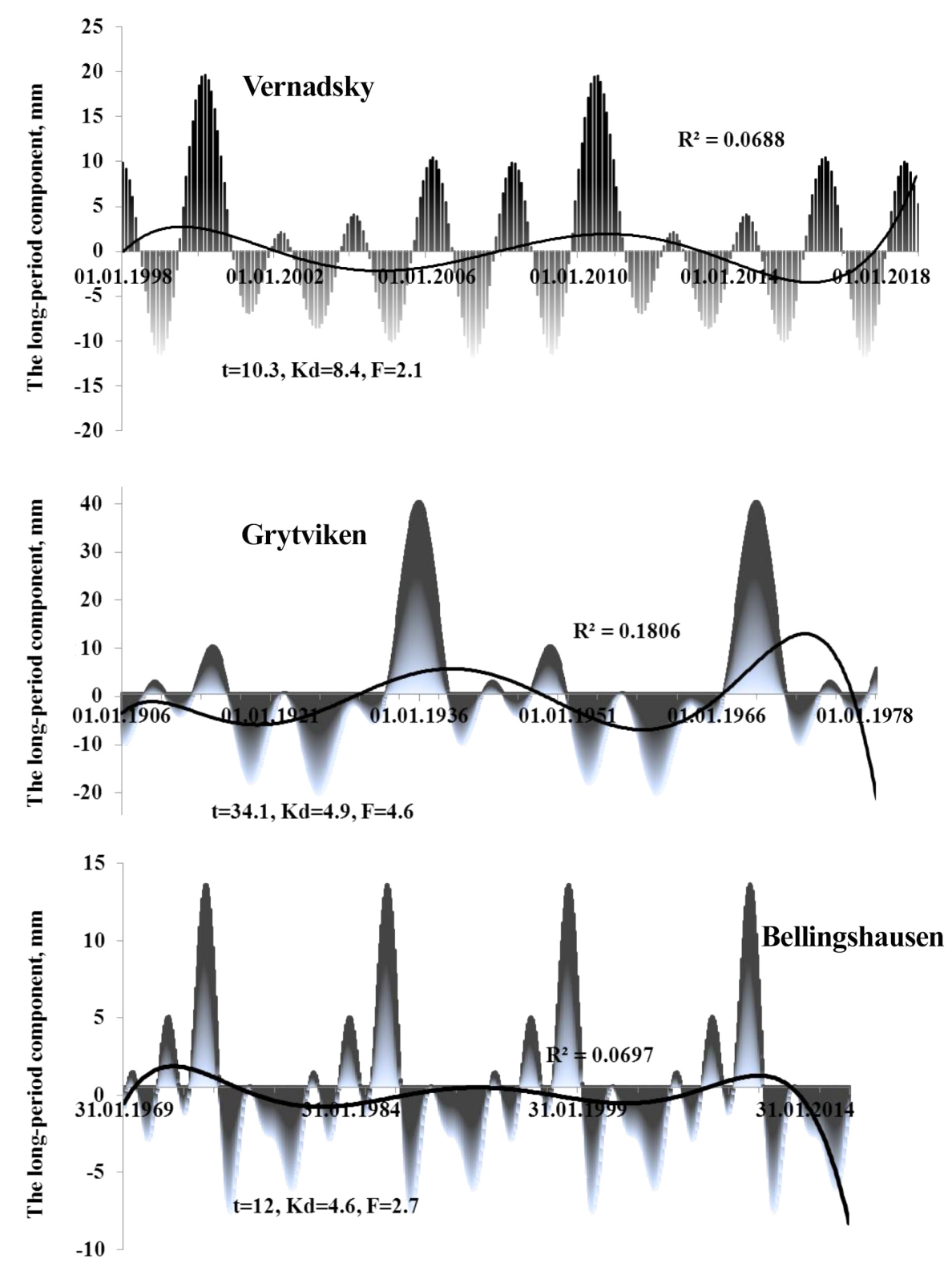

Fig. 6. The long-period component of precipitation variability according to observations at Vernadsky (1998-2018), Grytviken (1906-1981) and Bellingshausen (1969-2016) stations.

At Vernadsky station the period of variability is 10.3 years; $\mathrm{Kd}$ is $8.4 \%$ with an $\mathrm{F}$ statistic is 2.1. According to the data from Grytviken station, the period of longterm variability here is 34.1 years; $\mathrm{Kd}$ is $4.9 \%$ with an F-statistic of 4.6. And for Bellingshausen station the period of long-term variability is 12.0 years; $\mathrm{Kd}$ is $4.6 \%$ with an $\mathrm{F}$ statistic is 2.7 .

It is worth noting that in our case fairly good results were obtained, as for areas with difficult weather conditions, especially for Vernadsky research base. For Vernadsky station five statistically significant har- monics of the long-period precipitation variability were obtained, which are reflected in periods of 6.8, 2.4, 4.0, 5.1, and 5.3 years. At the same time for other station only 4 statistically significant harmonics were selected (fig. 7). In particular for Grytviken station four harmonics of the long-period precipitation variability were obtained, the periods of which are 4.2, 0.8, 1.7, and 8.9 years. For Bellingshausen station these periods are 1.5, 2, 2.8, and 0.2 years (for all stations the periods of fluctuations are listed because as decreasing of their strength). 

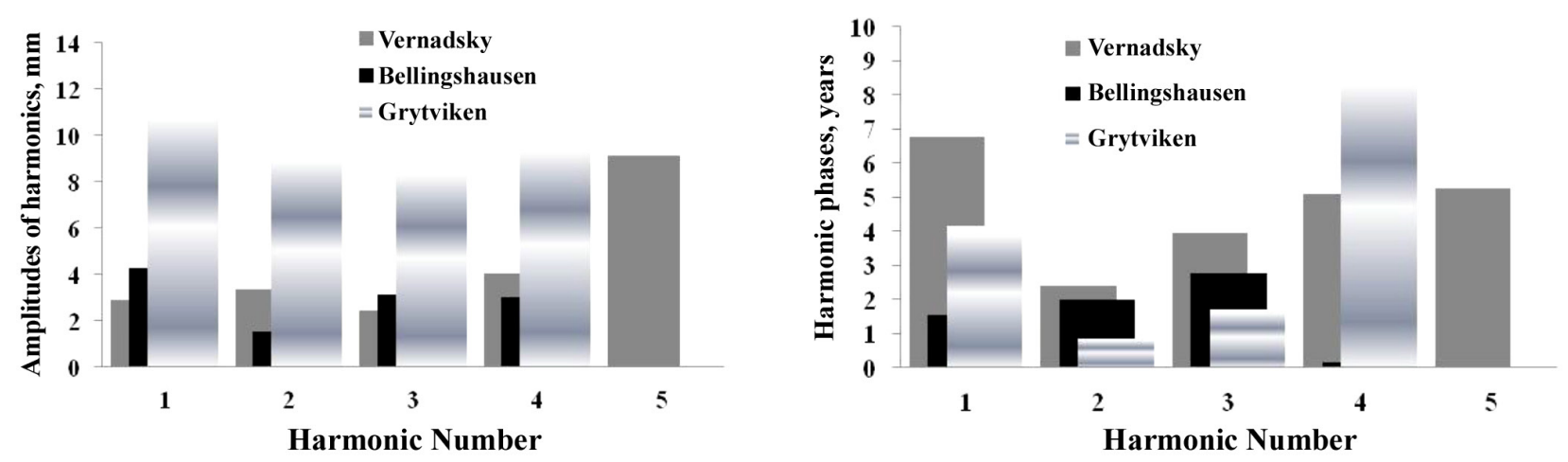

Fig. 7. Amplitudes and phases of harmonic of the long-period precipitation variability according to the data from Vernadsky (19982018), Grytviken (1906-1981) and Bellingshausen (1969-2016) stations.

To determine the boundaries of the variability first harmonics for Grytviken station (34.1 years), as periods, the $1^{\text {st }}$ harmonic was built, the period of well as for Bellingshausen station (12 years) are also which Vernadsky station is 10.3 years (Fig. 8). The shown on Fig. 8.

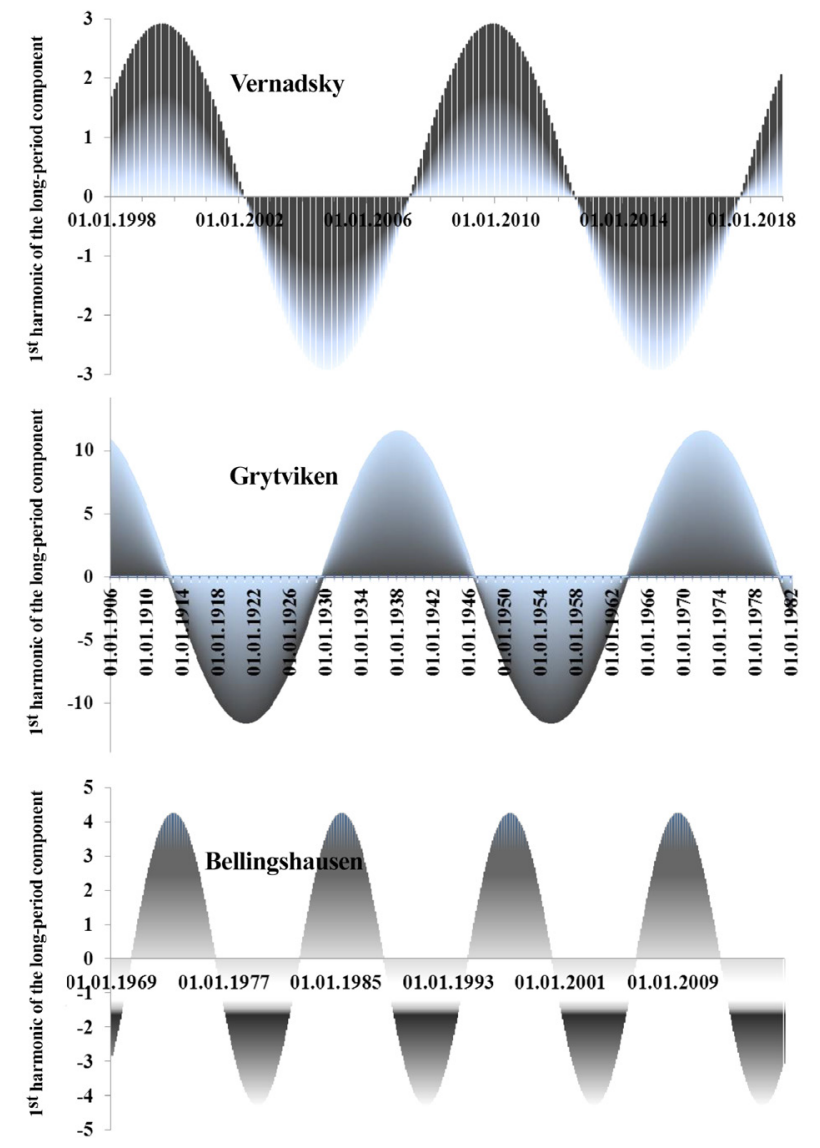

Fig. 8. General view of $1^{\text {st }}$ harmonic of the long-period component of precipitation amount according to the data from Vernadsky (1998-2018), Grytviken (1906-1981) and Bellingshausen (1969-2016) stations.

The authors were able to describe the variability of precipitation in $29.4 \%$ in the case of Vernadsky station, $15 \%$ at Bellingshausen station and $19.8 \%$ at Grytviken station. The authors were able to describe the variability of precipitation in $29.4 \%$ in the case of Vernadsky station, $15 \%$ at Bellingshausen station and $19.8 \%$ at Grytviken station. We can assume that there are other, slower periods of oscillation, other than those obtained in this work.

Today, the main phases of solar activity are well known, which are about 11 years old. The long-period components of atmospheric precipitation variability obtained in the work for the stations under consideration (to $10.3,12$ and 34.1 years) are identical (close) to the mentioned phase of solar forcing. This allowed 
drawing the preliminary conclusions about the influence of solar activity on the conditions for the formation of precipitation in the region under study. Despite the fact that the periods obtained by us are identical in duration to the periods of solar activity, it was not possible to obtain a clear correlation between them (fig. 9). So far, we have only used the direct pair correlation technique. Obviously, in the future, more detailed studies of this connection should be carried out using other mathematical methods.

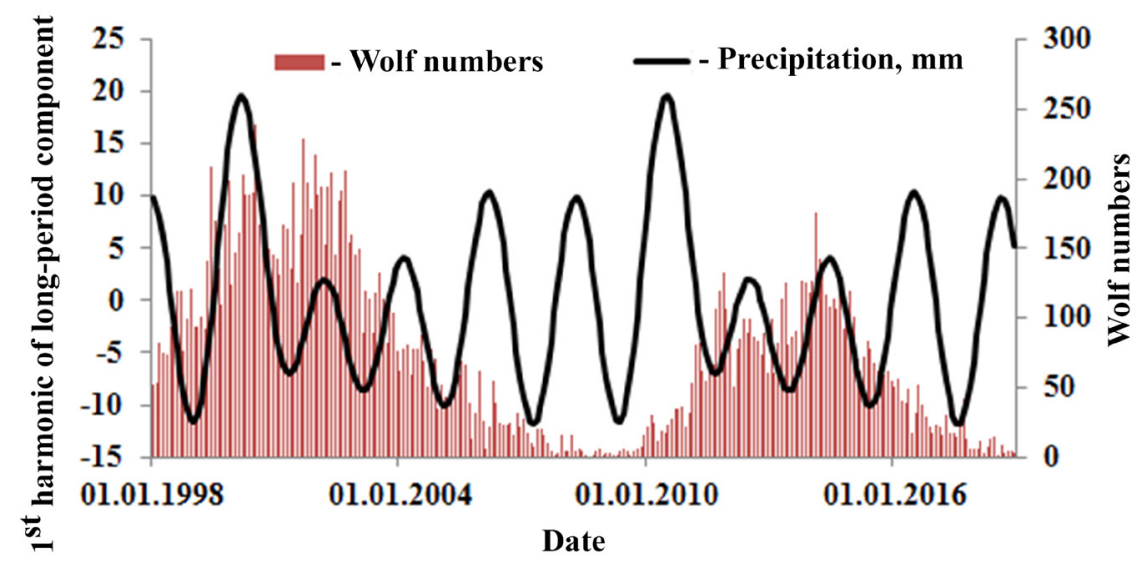

Fig. 9. The distribution of the long-period precipitation component $(T=10.3$ years $)$ according to observation from Vernadsky station relative to Wolf numbers for 1998-2018.

It is interesting to note that the performed analysis demonstrated the presence of a harmonic of about 4 years length at Vernadsky station as well as at Grüntwiken and Bellinghausen stations. With it that the intra-annual component of the precipitation amount variability can be associated, because in both cases it is such a periodicity that was found in the study of precipitation annual cource. We suggested that the 4-year periodicity is caused by El Niño/Southern Oscillation phenomenon (Oceanic... 2020), but their coordinated distribution showed on Fig. 10 does not confirm this.

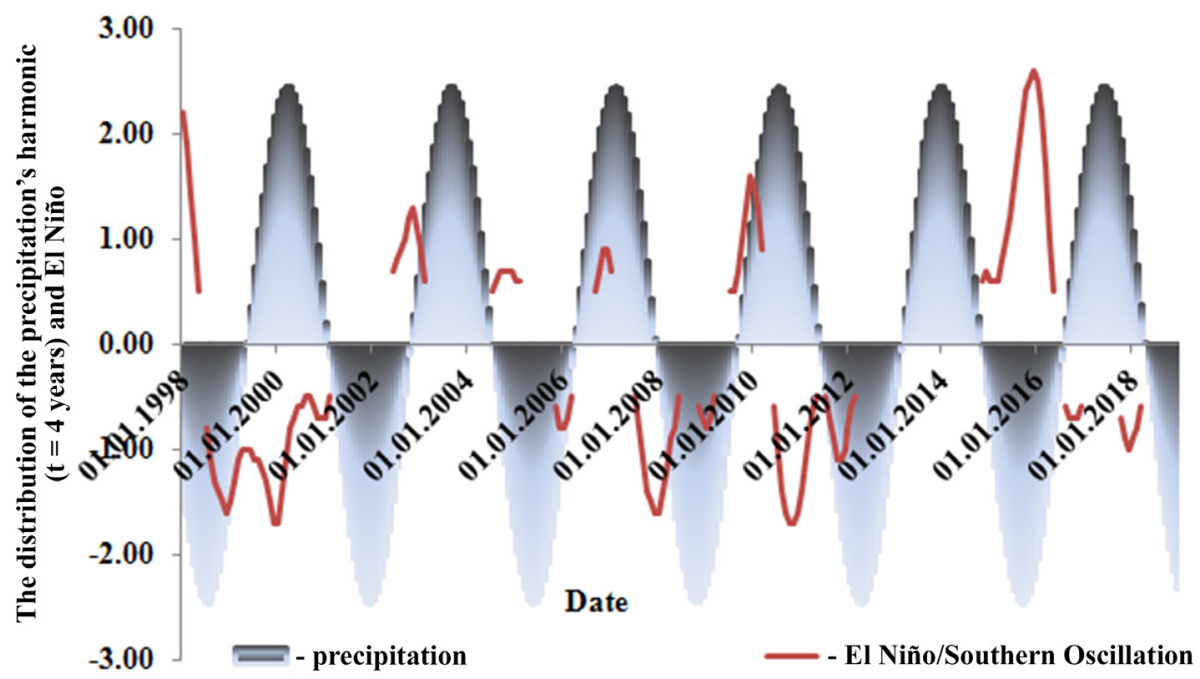

Fig. 10. The distribution of the precipitation's harmonic $(t=4$ years $)$ according to the data from Vernadsky and El Niño/Southern Oscillation coefficient for the period 1998-2018.

As in the case of the study of the influence of solar activity, it is necessary to expand the arsenal of methods in order to establish or refute this connection. It is necessary to look for other approaches to assessing the correlation, such as the lag method or sliding window correlation analysis.

\section{Conclusions.}

As a result of the study of monthly and annual precipitation amounts according to observations at Vernadsky and Grytviken stations, the characteristics of linear trends for these observations were obtained. In the case of Grytviken station the linear trend is turned out to be positive (0.015) and statistically significant 
$(\mathrm{Kd}=2.38, \mathrm{~F}=22.2)$, while on Vernadsky and Bellingshausen stations its values are statistically insignificant and very small.

The intra-annual component of precipitation variability in this work covers $19 \%$ of the total precipitation variability at Vernadsky station $12.5 \%$ at Grytviken station and $10.1 \%$ at Bellingshausen station. In the annual course, the component of precipitation variability is represented by 3 peaks - March, July and October, with a well-pronounced 4-year periodicity. However, data from Vernadsky station indicates a decrease of the seasonal component in time, while at Grytviken station the seasonal component is stable in time. In both cases, intra-annual variability was mainly determined by harmonics close to four-year ones, which suggests the certain role of the El Niño/ Southern oscillation phenomenon in its formation. The linear trend of this variability component in the case of Vernadsky station turned out to be $-0.01 \mathrm{~mm} /$ year with $\mathrm{Kd}=57.5$ and F-statistics of 25.96 at the Grytviken station it was statistically insignificant.

The analysis of the long-period components of the precipitation variability was carried out on the residuals of the data obtained after the analysis of the intra-annual component. For the long-period component of precipitation variability at Vernadsky station, five statistically significant harmonics were obtained, which are reflected in periods of 6.8, 2.4, 4.0, 5.1, and 5.3 years. For the Grytviken station, 4 statistically significant harmonics were obtained, the periods of which are 4.2, 0.8, 1.7, 8.9 years, as well

\section{References}

Averyanov, V.G., 1990. Glyatsio-klimatologiya Antarktidyi [Glacio-climatology of Antarctica]. Gidrometeoizdat, Leningrad: 198 (in Russian).

Blattner, P., Cook K., Ulrich L., Dyck T., 1999. Special Edition Using Microsoft Excel 2000. Que Publishing, Indianapolis: 1088 .

Bogdanova, E.G., Il'in, B.M. \& Gavrilova, S.Y., 2007. Sovremennyie metodyi korrektirovki izmerennyih osadkov i rezultatyi ih primeneniya v polyarnyih regionah Rossii i Severnoy Ameriki [Advanced methods for correcting measured precipitation and results of their application in Polar Regions of Russia and North America]. Russian Meteorology and Hydrology 32(4): 229-244. doi: https://doi. org/10.3103/S 1068373907040036 (in Russian).

Bromwich, D. H., 1988. Snowfall in High southern latitudes. Reviews of. Geophysics 26(1): 149-168. doi: https://doi. org/10.1029/RG026i001p00149

Brooks, C. E. P. \& Carruthers N., 1953. Primenenie statisticheskih metodov v meteorologii [Handbook of statistical methods in meteorology]. Meteorological Office, London: 412 p. doi: https://doi.org/10.1002/ qj.49707934226 (in Russian). as 1.5, 2.0, 2.8, 0.2 years for Bellingshausen stations. The presence of harmonics the size of which is about 4 years, both at Vernadsky station and at Grytviken station, suggests that it is associated with the intraannual component of variability of the precipitation amount (at both stations, such a periodicity was found when studying intra-annual variability). Comparing the distribution of this harmonic of precipitation amount and El Nino/Southern Oscillation coefficients, it can be assumed that the 4-year periodicity is caused by this phenomenon.

The commensurate periods of long-period oscillations obtained by us, equal to $10.3,12.0$ and 34.1 years, can serve as confirmation that the components of solar forcing variations are significantly involved in the formation of atmospheric precipitation in the studied region.

Climate models and observations are improving all the time and the reliability of predictions is likely to improve significantly over the next few years. In particular, new satellites and more detailed models are opening up new possibilities for understanding and predicting how precipitation cycles through the climate system. Considering the fact that the authors were able to describe the variability of precipitation in $29.4 \%$ in the case of Vernadsky station, $15 \%$ at Bellingshausen station and $19.8 \%$ at Grytviken station, we can assume that there are other, slower periods of oscillation, other than those obtained in this work. The limited observational data used by us did not make it possible to conduct more advanced studies for today.

Bryazgin, N. N., 1982. Atmospheric precipitation in Antarctica. Polar Geography and Geology 6(3): 210 218. doi: https://doi.org/10.1080/10889378209377167

Cullather R. I., Bromwich D. H., van Woert M. L. 1996. Interannual variations in Antarctic precipitation related to El-Nino-Southern Oscillation. Journal of Geophysical Research 101(D 14): 19109-19118. doi: https://doi. org/10.1029/96JD 01769

Hayhoe. K., Wuebbles D. J., Easterling D. R., Fahey D. W., Doherty S., Kossin J., Sweet W., Vose R. and Wehner M., 2018. Our Changing Climate. In Impacts, Risks, and Adaptation in the United States: Fourth National Climate Assessment, Volume II. U. S. Global Change Research Program, Washington, DC: 72-144. doi: https://doi. org/10.7930/NCA4.2018.CH2

Kirchgäßner, A. 2011., An analysis of precipitation data from the Antarctic base Faraday/Vernadsky. International Journal of Climatology 31: 404-414. doi: https://doi. org/10.1002/joc. 2083

Klok, S.V., 2010. Osoblyvosti vymiriuvannia atmosfernykh opadiv na Ukrainskii antarktychnii stantsii Akademik Vernadskyi [Features of measurement of an atmospheric precipitation at the Ukrainian Antarctic station 
Academician Vernadsky]. Ukrainian Antarctic Journal 9: 222-230. (in Ukrainian).

Klok, S.V., 2013. Rozpodil atmosfernykh opadiv za danymy sposterezhen na Ukrainskii antarktychnii stantsii «Akademik Vernadskyi» [The distribution of precipitation on the observations on Ukrainian Antarctic station Academician Vernadsky]. Hydrology, hydrochemistry and hydroecology. 3(30): 98-104. (in Ukrainian)

Lapin, M., Nieplová E., Faško P., 1995. Regional scenarios of temperature and precipitation changes for Slovakia. In National Climate Programme of Slovakia. Bratislava, SHMI and Slovak Ministry of the Environment, 3: 1757. (in Slovak).

Malcolm S. Y., Tang S. N., Chenoli S., Colwell R., Grant M. S., Law J., Samah A. A., 2018. Precipitation instruments at Rothera Station, Antarctic Peninsula: a comparative study. Polar Research, 37:1, doi: https://doi. org/10.1080/17518369.2018.1503906

Mouginot, J., Rignot E., Bjørk A.A., van den Broeke M., Millan R., Morlighem M., Noël B., Scheuchl B., Wood M., 2019. Forty-six years of Greenland Ice Sheet mass balance from 1972 to 2018. Proceedings of the National Academy of Sciences 116 (19): 9239-9244. doi: https://doi.org/10.1073/pnas.1904242116

Oceanic Niño Index, 2020. National Oceanic and Atmospheric Administration. Washington. Retrieved from URL: https://origin.cpc.ncep.noaa.gov/products/ analysis_monitoring/ensostuff/ONI_v5.php

Pachauri, R.K., Meyer L.A. (eds.), 2014. Climate Change 2014: Synthesis Report. Contribution of Working Groups I, II and III to the Fifth Assessment Report of the Intergovernmental Panel on Climate Change. Geneva, IPCC: 151.

Raveendranathan, D., 2018. Developments Lead to Pollution and Depletion of Natural Resources. Chennai, Notion Press: 228.

Rignot, E., Mouginot J., Scheuchl B., van den Broeke M., Millan R., Morlighem M., Noël B., Scheuchl B., Wood M., 2019. Four decades of Antarctic Ice Sheet mass balance from 1979-2017. Proceedings of the National Academy of Sciences 116 (4): 1095-1103. doi: https://doi.org/10.1073/pnas.1812883116

Sedunov, Yu.S., Avdyushin S. I., Borisenkov E. P. (eds), 1991. Atmosfera [Atmosphere]. Reference book. Gidrometeoizdat, Leningrad: 512. (in Russian).

Shukla, P.R., Skea J., Calvo Buendia E., MassonDelmotte V., Pörtner H.-O., Roberts D. C., Zhai P., Slade R., Connors S., van Diemen R., Ferrat M., Haughey E., Luz S., Neogi S., Pathak M., Petzold J., Portugal Pereira J., Vyas P., Huntley E., Kissick K., Belkacemi M., Malley J., (eds.), 2019. Climate Change and Land. An IPCC special report on climate change, desertification, land degradation, sustainable land management, food security, and greenhouse gas fluxes in terrestrial ecosystems. Geneva, IPCC: 874.

Stocker, T.F., Qin D., Plattner G.-K., Tignor M., Allen S. K., Boschung J., Nauels A., Xia Y., Bex V. and Midgley P. M. (eds.), 2013. Climate Change. The Physical Science Basis. Contribution of Working Group I to the Fifth Assessment Report of the Intergovernmental Panel on Climate Change. Cambridge University Press, Cambridge: 1552.

Thomas, R.H., 1963. Studies on the ice cap of Galindez Island, Argentine Islands. British Antarctic Survey Bulletin 2: 27-43.

Total sunspot number, 2020. Sunspot Index and Long-term Solar Observations. Brussels: Royal Observatory of Belgium. Retrieved from URL: http://sidc.oma.be/silso/ datafiles

Trenberth, K.E., 2011. Changes in precipitation with climate change. Climate Research 47: 123-138. doi: https://doi. org/10.3354/cr00953

Turner, J., Barrand N. E., Bracegirdle T. J., Convey P., Hodgson D. A., Jarvis M., Jenkins A., Marshall G., Meredith M. P., Roscoe H., Shanklin J., French J., Goosse H., Guglielmin M., Gutt J., Jacobs S., Kennicutt M. C., Masson-Delmotte V., Mayewski P., Navarro F., Robinson S., Scambos T., Sparrow M., Summerhayes C., Speer K., Klepikov A., 2014. Antarctic climate change and the environment: an update. Polar record 50(3): 237-259. doi: https://doi. org/10.1017/S 0032247413000296

Turner, J., Lachlan-Cope T.A., Thomas J. P., Colwell S. R., 1995. The synoptic origins of precipitation over the Antarctic Peninsula. Antarctic Science 7(3): 327-337. doi: https://doi.org/10.1017/S 0954102095000447

Turner, J., Leonard S., Lachlan-Cope T., Marshall G. J. 1998. Understanding Antarctic Peninsula precipitation distribution and variability using a numerical weather prediction model. Annals of Glaciology 27: 591-596. doi: https://doi.org/10.3189/1998AoG27-1-591-596

van Vuuren, D.P., Edmonds J., Kainuma M., Riahi K., Thomson A., Hibbard K., Hurtt G. C., Kram T., Krey V., Lamarque J.-F., Masui T., Meinshausen M., Nakicenovic N., 2011. The representative concentration pathways: an overview. Climatic Change 109: 5-31. doi: https://doi.org/10.1007/s10584-011-0148-z

Velicogna, I., 2009. Increasing rates of ice mass loss from the Greenland and Antarctic ice sheets revealed by GRACE. Geophysical Research Letters 36: L19503. doi: https://doi.org/10.1029/2009GL040222 